\title{
GROWTH AND SKULL DEVELOPMENT IN THE SOUTH AMERICAN FUR SEAL, ARCTOCEPHALUS AUSTRALIS (ZIMMERMANN, 1783) (CARNIVORA: OTARIIDAE), FROM RIO GRANDE DO SUL COAST, BRAZIL
}

\author{
Daniza Molina-Schiller ${ }^{1,2}$ and Maria Cristina Pinedo ${ }^{2}$
}

\begin{abstract}
Skulls of 157 Arctocephalus australis (94 males and 63 females) from animals stranded dead on the Rio Grande do Sul coast from Torres to Barra do Arroio Chuí between July 1977 and September 1997 were examined. These were analyzed to explore aspects of the cranial development. The growth layers groups (GLGs) in the dentine and cementum from upper canine teeth were counted. The oldest male and female were 14 and 18 years of age, respectively. Parameters of the von Bertalanffy equation suggest that males and females attain physical maturity at about the eight and six years of age, respectively. Hotelling $\mathrm{T}^{2}$ test and discriminant functions using metric characters showed sexual dimorphism in physically mature and immatures skulls. The developmental classes were also examined using non-metric characters, but no sexual dimorphism was observed using these variables. The principal component analysis (PCA) showed a clear separation between physically mature skulls of males and females. The first factor explained $80.2 \%$ of the total variation and the second factor explained $4.6 \%$ of the observed variability.

Resumen - Fueron examinados 157 cráneos de Arctocephalus australis (94 machos y 63 hembras) provenientes de animales muertos en la costa de Río Grande do Sul, desde Torres hasta la Barra do Arroio Chuí entre Julio 1977 a Septiembre 1997. Estos cráneos fueron analizados para explorar el desarrollo craniano. En dientes caninos superiores fueron contados los grupos de capas de crecimiento (GLGs) en la dentina y cemento. El macho y hembra de mayor edad fue de 14 años y 18 años, respectivamente. Parámetros de la ecuación de von Bertalanffy sugieren que los machos y hembras alcanzarían la madurez física aproximadamente a los ocho y seis años de edad, respectivamente. Análisis de test Hotelling $\mathrm{T}^{2}$ y funciones discriminantes utilizando los caracteres métricos mostraron dimorfismo sexual en cráneos físicamente maduros y físicamente inmaduros. Las clases de desarrollo también fueron examinadas usando caracteres no-métricos, pero el dimorfismo sexual no fue observado usando estas variables. El análisis de componentes principales (PCA) mostró una clara separación entre cráneos de machos y hembras físicamente maduros. El primer factor explico $80.2 \%$ de la variación total y el segundo factor explico $4.6 \%$ de la variabilidad observada.
\end{abstract}

Keywords: age estimation, Arctocephalus australis, growth, physical maturity, sexual dimorphism, southern Brazil.

\section{Introduction}

The South American fur seal, Arctocephalus australis, is widely distributed from Rio de Janeiro $\left(23^{\circ} 18^{\prime} \mathrm{S}, 44^{\circ} 30^{\prime} \mathrm{W}\right)$,

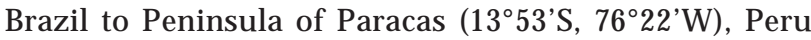
(Bonner, 1981; Majluf and Trillmich, 1981; Vaz-Ferreira, 1982; Pinedo et al., 1992; Jefferson et al., 1993). In Uruguay the species breeds on the Isla del Marco, in the Castillos group $\left(34^{\circ} 21^{\prime} \mathrm{S}, 53^{\circ} 5^{\prime} \mathrm{W}\right)$; on the Islote Encantada and Isla Rasa, in the Torres group ( $\left.34^{\circ} 24^{\prime} \mathrm{S}\right)$, mainly on the Isla de Lobos $\left(35^{\circ} 01^{\prime} \mathrm{S}\right)$, and also on the Islote (Vaz-Ferreira, 1982). The population was estimated at 300000 individuals in 1996 (Páez, 1999).

A. australis is one of the most common pinniped species in the coast of Rio Grande do Sul, occurring mainly during fall and winter. Most of the strandings in Rio Grande do Sul coast probably originate from Uruguay. Given that most of them are found dead or debilitated, physical exhaustion or diseases are suspected (Pinedo, 1990).

Morphometric studies on the South American fur seal are limited. Repenning et al. (1971) described the characteristics of the skull of nine adult males of the Falklands Islands. Sexual dimorphism in size and shape was observed on adult skulls (24 males and 24 females) of A. australis from Uruguay (Ximénez et al., 1984). Páez
(1989) analyzed the cranial development of 286 individuals from Uruguay (Isla de Lobos and Cabo Polonio), based on morphometric variables, and the ages were estimated from upper canines teeth bisectioned longitudinally and decalcified in a solution of $5 \%$ formic acid. Batallés et al. (1990) studied the external development in 500 females and 500 males of the Isla de Lobos. Oliveira (1999), Brunner (2000), Oliveira and Danilewicz (2000), Oliveira et al., (2001) and Sanfelice (2004) also studied skull shape and size in the South American fur seal using traditional and geometric morphometrics techniques.

In taxonomical and stock identification studies it is recommended that comparisons among different geographic populations be preceded by identification of the individual variation in adults that occur within populations (Perrin, 1984; Schnell et al., 1985). However, before identifying variation at the individual and population levels, studies of the ontogenetic variation and age estimation are required to select the physically mature individuals to avoid selecting traits related with development, i.e., those expressed by physically immature individuals (Calzada, et al., 1997; Brunner, 2000).

In this study the metric and non-metric characters were used as a function of age to explore the growth pattern of

\footnotetext{
${ }^{1}$ Current address: Universidade Federal do Rio Grande do Sul, Pós-Graduação em Ecologia. Av. Bento Gonçalves 9500. Cx. Postal 15007, Porto Alegre RS 91540-000 Brazil. E-mail: daniza@marinemammals.cl.

${ }^{2}$ Fundação Universidade Federal do Rio Grande (FURG), Departamento de Oceanografia. Caixa Postal 474, Rio Grande RS 96201-900 Brazil.
} 
A. australis and detect individual variation in males and females occurring in Rio Grande do Sul coast, Brazil.

\section{Material and Methods}

\section{Study area}

Skulls of 157 A. australis (94 males and 63 females) of animals found dead on the coast of Rio Grande do Sul $(612 \mathrm{~km}$ of beach) from Torres $\left(29^{\circ} 20^{\prime} \mathrm{S}, 49^{\circ} 44^{\prime} \mathrm{W}\right)$ to Barra do Arroio

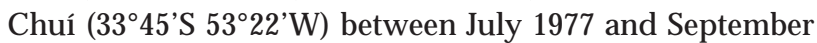
1997 were examined (Figure 1). This coast has been surveyed as part of a long-term beach monitoring program conducted by the Laboratory of Marine Mammals and Marine Turtles (LMM) of the Oceanography Department of the Fundação Universidade Federal do Rio Grande (FURG), Brazil. The analyzed skulls are deposited at LMM.

\section{Analysis of metric characters and age estimation}

Nineteen cranial measurements were utilized (Table 1, Figure 2). Seventeen measurements were previously used by Repenning et al. (1971), Ximénez et al. (1984) and Páez (1989). Rostral width and greatest width of internal nasal opening were introduced for the first time (Figure 2).

Due to missing or broken bones in some skulls, sample sizes varied for each collected measurement. In cases of characters presenting symmetry, the left side was measured. The number of teeth and/or presence of alveoli in each mandibular and maxillary branch were counted.

The von Bertalanffy equation (1957) was used to describe cranial development for each variable according to sex and to determine which variables were correlated with age. The von
Bertalanffy equation is expressed by $\mathrm{L}_{\mathrm{t}}=\mathrm{L}_{¥}\left(1-\mathrm{e}^{-\mathrm{k}(\mathrm{t}-\mathrm{t})}\right)$, where: $L_{t}$ is the value of the measure at age $t$ (e.g., metric characters); $t$ is a unit of time in years (estimated from growth layer groups present in each tooth ); $t_{0}$ is the hypothetical age at which $A$. australis has length equals zero, assuming individual always growth in the manner described by the equation; $L_{\gamma}$ is the asymptotic length (e.g., the average length the species reaches if it grows indefinitely); $k$ is the growth-rate constant and $e$ is the natural logarithm base. These parameters were obtained using the interaction quasi-Newton method (non-linear module) of the Statistics 6.0 for Windows. Growth curves were calculated for males and females.

Ages were estimated from counts in the upper canine teeth. The growth layer groups (GLGs) in the dentine and cementum of the teeth were counted. Two techniques were used for age estimation. The first technique used was decalcified and stained thin sections. Teeth were decalcified with RDO ${ }^{\circledR}(a$ rapid commercial bone decalcifier), and cut longitudinally using a $\mathrm{CO}_{2}$ freezing microtome. On-center sections 25 to $30 \mathrm{~mm}$ thick were stained in Harris' hematoxylin and examined under transmitted light according to Molina and Oporto (1993), Molina-Schiller (2000) and Molina-Schiller and Pinedo (2004). The second technique was half-tooth etched in $5 \%$ formic acid and rubbed with graphite powder according Schiavini et al. (1992) and Crespo et al. (1994). We interpreted each GLG as equivalent to one year's growth (Perrin and Myrick, 1980; Schiavini et al., 1992; Crespo et al., 1994).

The age of attainment of physical maturity $(t)$ in the skull was obtained by visual analysis of each variable in relation to the stabilization of the growth curve. Only variables with a high correlation $(r \geq 0.90)$ in the von Bertalanffy curve were selected for growth analysis.

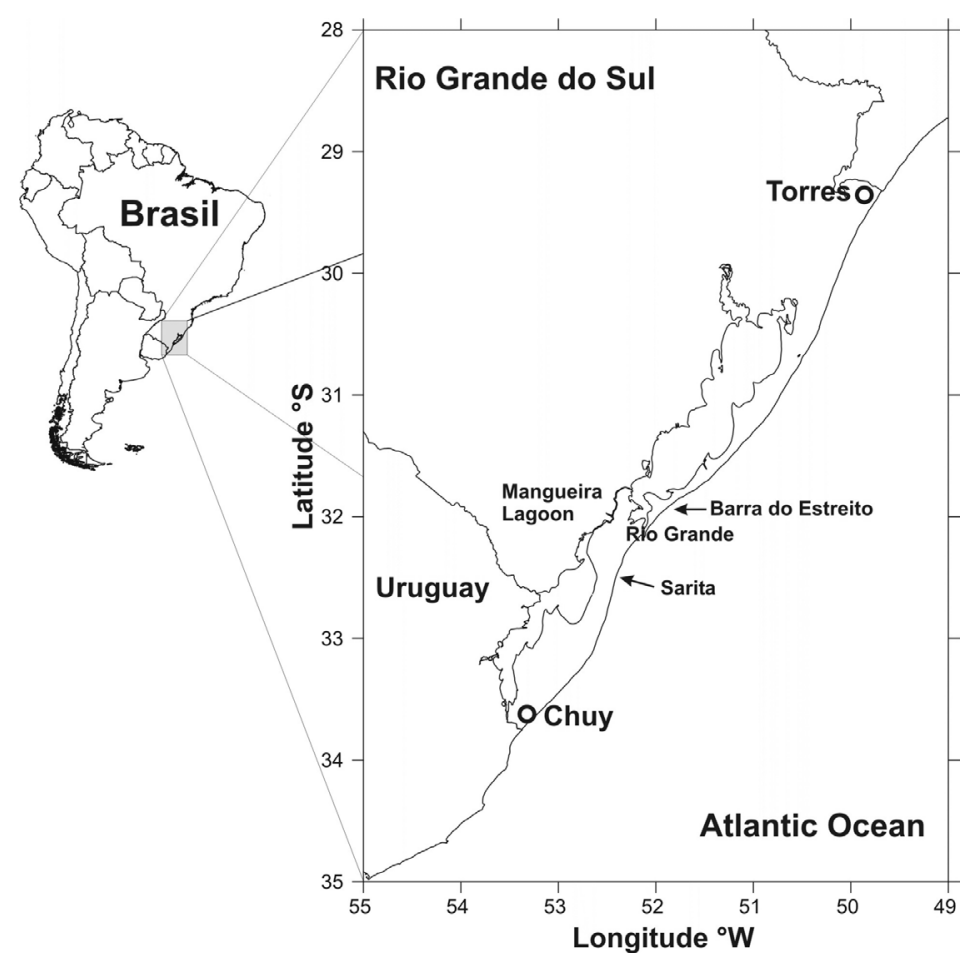

Figure 1. Areas of collection of Arctocephalus australis on the coast of Rio Grande do Sul, Brazil. 


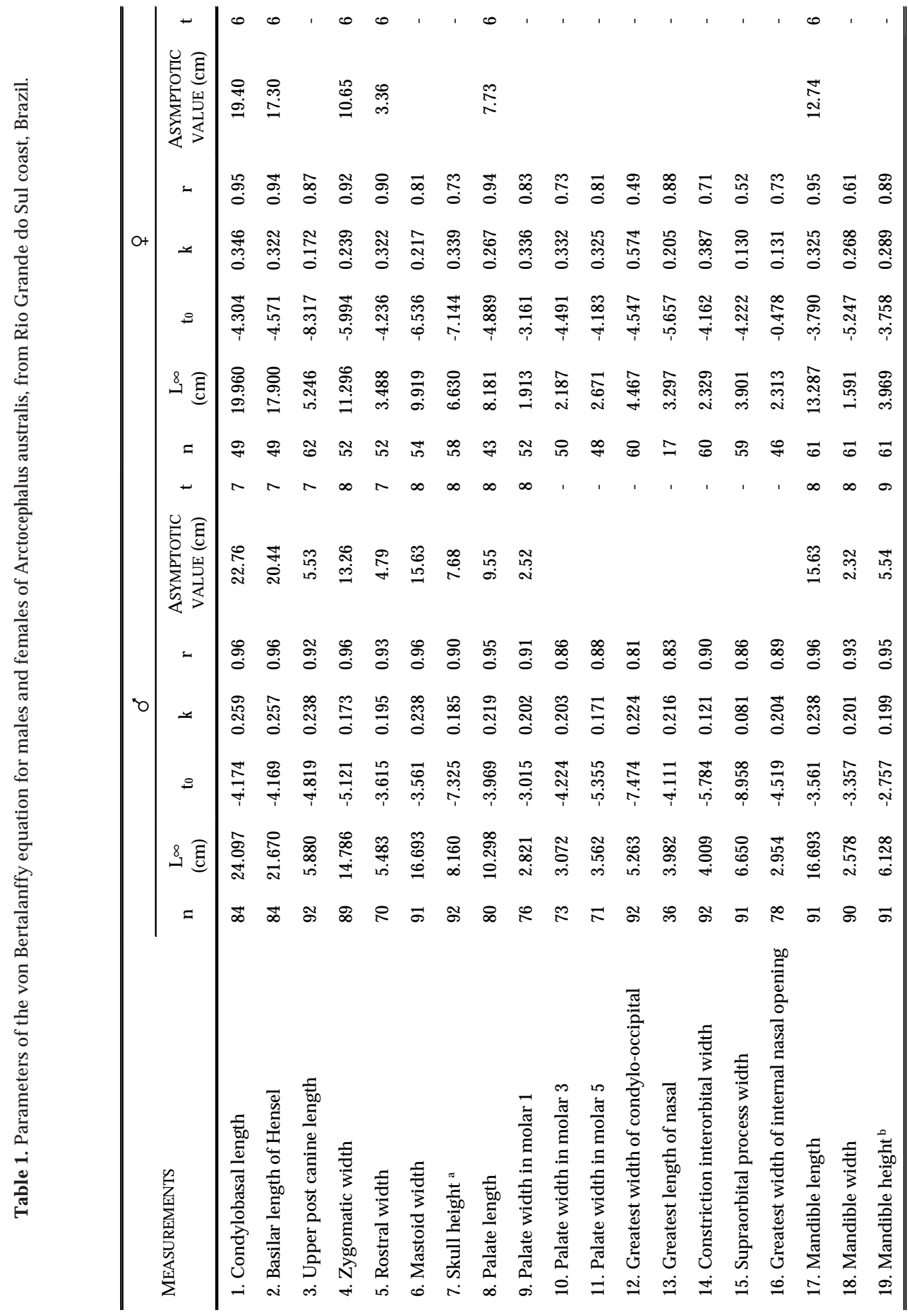




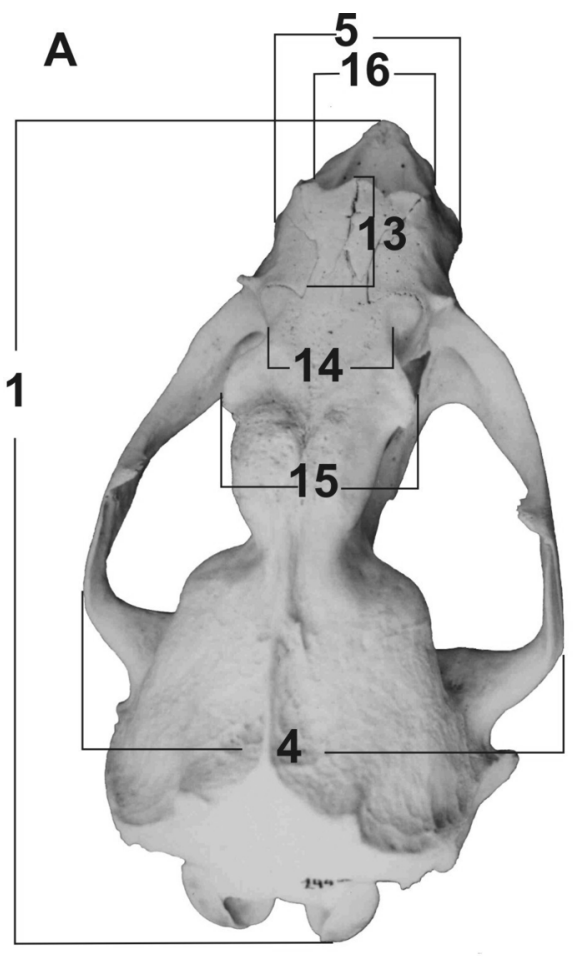

B
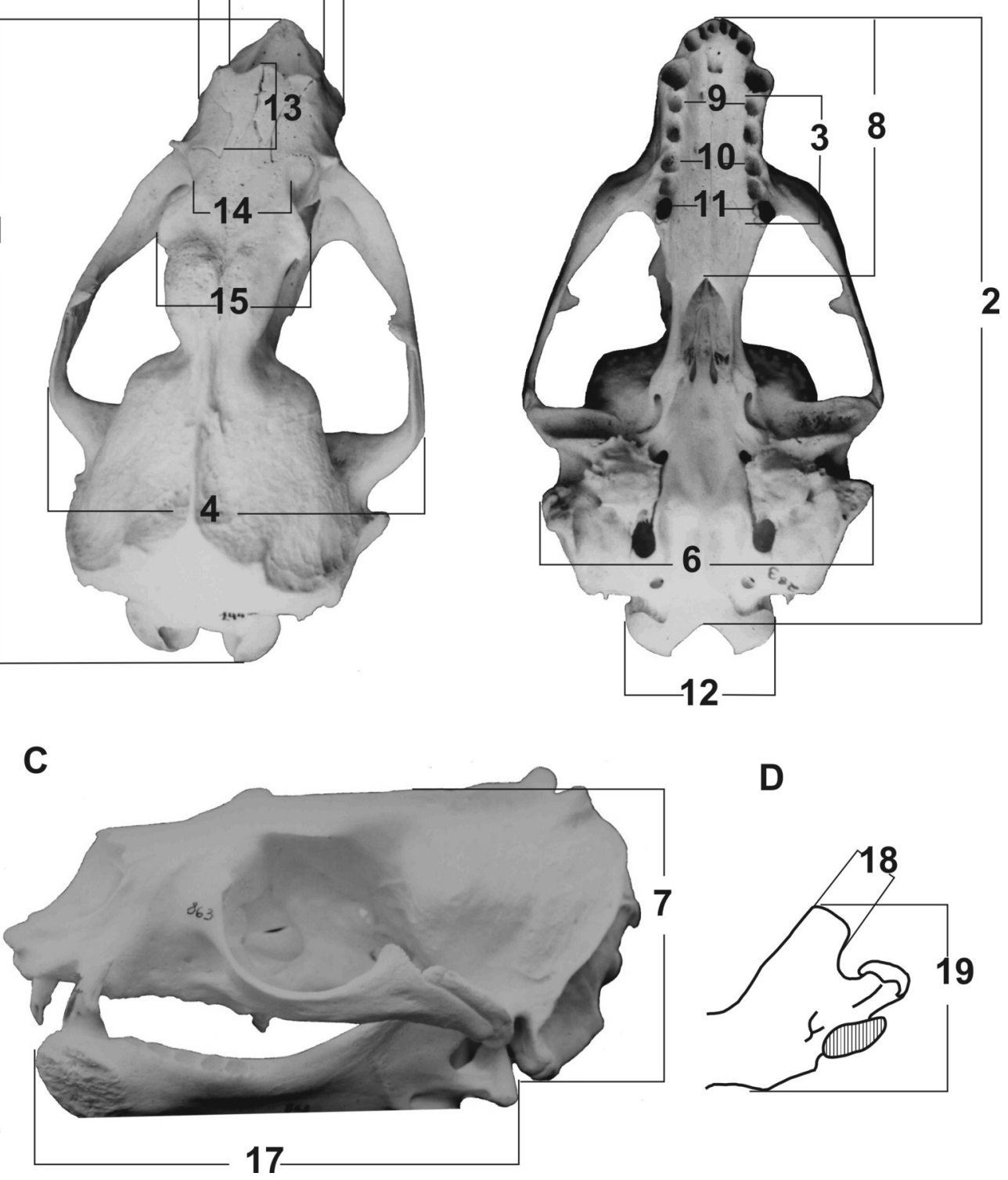

D

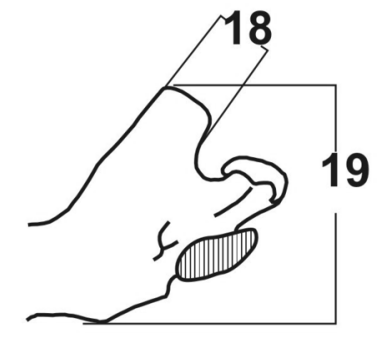

Figure 2. Skull metric characters of Arctocephalus australis. 1. Condylobasal length, 2. Basilar length of Hensel, 3. Upper post canine length, 4. Zygomatic width, 5. Rostral width, 6. Mastoid width, 7. Skull height (at insertion basisphenoidal-interparietal-occipital suture), 8. Palate length, 9. Palate width in molar 1, 10. Palate width in molar 3, 11. Palate width in molar 5, 12. Greatest width of condylo-occipital, 13. Greatest length of nasal, 14. Constriction interorbital width, 15. Supraorbital process width, 16. Greatest width of internal nasal opening, 17. Mandible length, 18. Mandible width, 19. Mandible height (at coronoid process).

Differences between physically mature and immature males and females were examined by Hotelling $\mathrm{T}^{2}$ multivariate test and a stepwise discriminant analysis using Statistic 6.0 for Windows. A discriminant score function was performed to ascertain sex.

\section{Analysis of non-metric characters}

The analyses of non-metric characters of the skull were based on the work of Sivertsen (1954). For the analyses of ontogenetic variation, physical maturity and of individual variation, we choose as characters the closure level of four cranial sutures, the opening level of the pulp cavity and the degree of wear at the apex of the crown of the upper canine teeth. The cranial sutures used in this study were: occipito-parietal, interparietal, premaxillary-maxillary, and interfrontal. The criteria used for the analyses of the cranial sutures were: $0=$ open, $1=$ closedvisible, 2 =closed-invisible (Figure 3). In the upper canine teeth the characters analyzed were the degree of opening of the pulp cavity and the criteria used were $0=$ open, $1=$ open (smaller or equal to $2 \mathrm{~mm}$ ) and $2=$ closed. The degree of wear the apex of the crown the criteria were: $0=$ absence and $1=$ presence. The analysis of Kolmogorov-Smirnov (K-S) for two independent samples was applied to determine if these characters were dimorphic in adult individuals. 
A

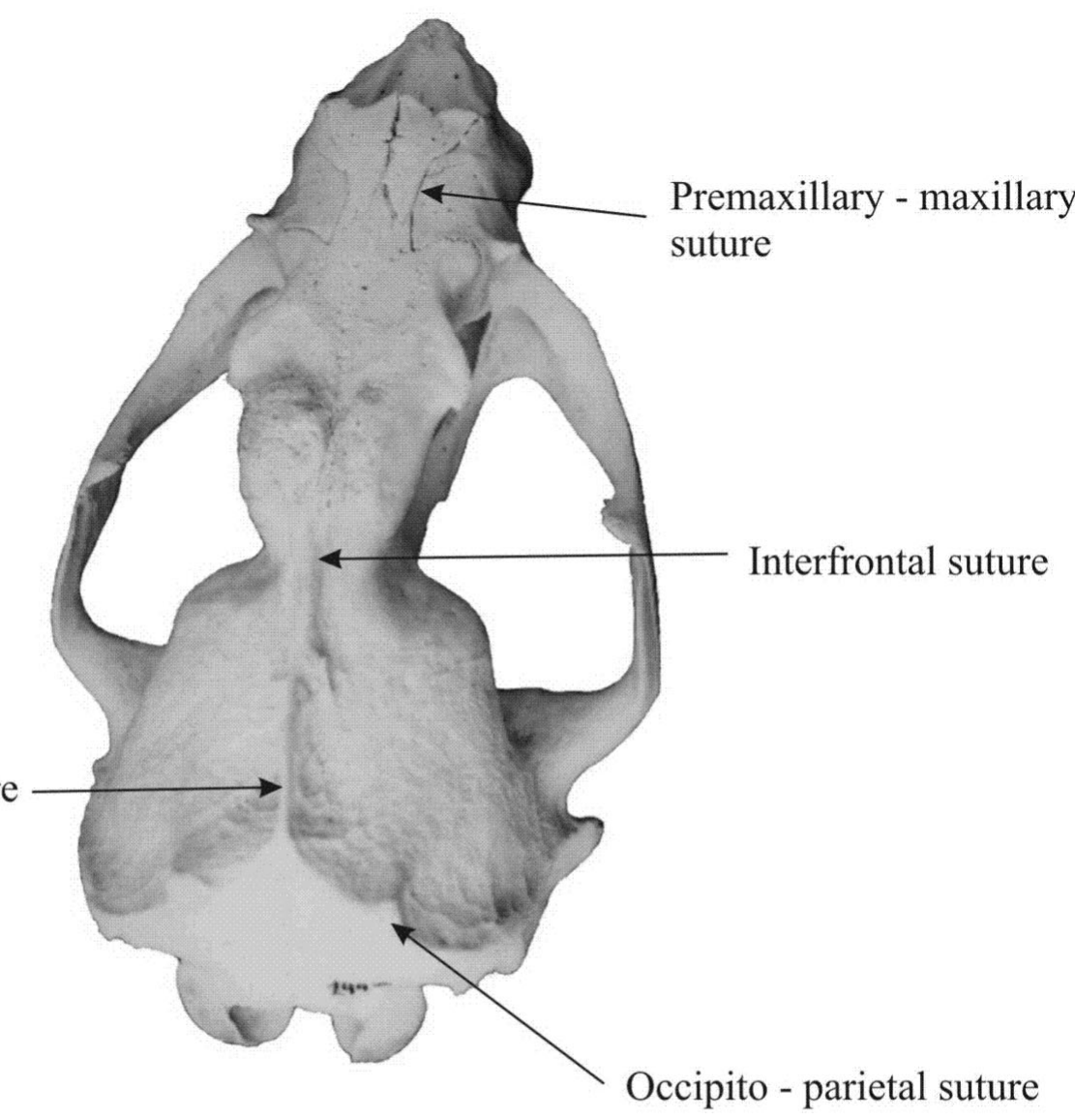

B

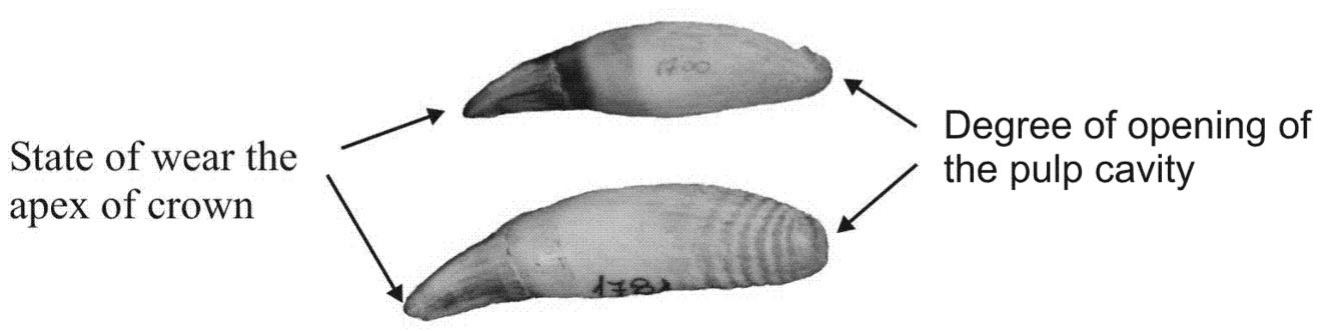

Figure 3. Non-metric characters of the skull of Arctocephalus australis. a) sutures and b) state of wear at the apex of the crown in the upper canine tooth and degree of opening of the pulp cavity.

\section{Individual variation}

Parametric and non-parametric methods of univariate and multivariate analyses (Zar, 1984) were utilized to identify the metric and non-metric characters which correlated with age, and selected those that best expressed the individual variation. The analysis of the individual variation through coefficients of variation (CV\%) was applied only to physically mature skulls, assuming these specimens represented a single panmictic population, and that the study population originated from the colonies in Uruguay (Pinedo, 1990). To detect the more suitable variables expressing the variation in the population, the criterion of Simpson et al. (1960 apud Pinedo, 1991) was used as guideline. However, a principal components analysis (PCA) with MD deletion case wise was applied to investigate the variation of all variables within each group. The method was applied with Statistic 6.0 for Windows.

\section{Results}

\section{Analysis of metric characters}

In this study the oldest male and female were 14 and 18 years of age, respectively. The parameters of fitted von Bertalanffy curves differed between males and females (Table 1, Figure 4). The correlation coefficient $(r)$ obtained through the von Bertalanffy model revealed that 13 characters $(68.4 \%)$ in males and six characters $(32 \%)$ in females presented a larger correlation with the age $(r \geq 0.90)$ (Table 1). 
The variables expressing higher correlation with age in males $(r=0.96)$ were condylobasal length, basilar length of Hensel, mastoid width, mandible length and zygomatic width. In females $(r=0.95)$, those were condylobasal length and mandible length (Table 1).

The growth constant $(k)$ was greater for females than for males (Table 1). In males, the condylobasal length and basilar length of Hensel presented the faster growth ( $k=0.26)$, followed by the upper post canine length and the mandible length $(k=0.24)$. A slower growth was observed in the supraorbital process width $(k=0.08)$ and the constriction interorbital width $(k=0.12)$ (Table 1$)$.

In females, the greatest width of condylo-occipital presented the faster growth $(k=0.57)$, followed by the constriction interorbital width $(k=0.39)$, condylobasal length $(k=0.35)$, skull height and palate width in molar 1 $(k=0.34)$. The supraorbital process width had a slower growth $(k=0.12)$, followed by the greatest width of internal nasal opening $(k=0.13)$ (Table 1$)$.

Differences were observed in the stabilization of the asymptotic growth of the variables selected with $r \geq 0.90$. In males, the stabilization of the asymptotic growth of the condylobasal length, basilar length of Hensel, upper post canine length and rostral width started at seven years of age (Table 1, Figure 4a). The stabilization of the asymptotic growth started at eight years of age in six variables (zygomatic width, mastoid width, skull height, palate length, palate width in molar 1 and upper post canine length) (Table 1, Figure 4b). However, the stabilization of the mandible height started at nine years of age (Table 1, Figure 4c). Considering that the average age of all variables selected was eight years, we suggest that males attain physical maturity about the eight years of age in our study area.

In females, the stabilization of the asymptotic growth began at six years of age in six variables (condylobasal length, basilar length of Hensel, rostral width, zygomatic width, palate length and mandible length) (Table 1, Figures $4 a, b)$. Therefore, we considered that females attain physical maturity at about six years of age.

The results of the Hotelling $\mathrm{T}^{2}$ multivariate test showed than in male and female skulls all variables were dimorphic $\left(\mathrm{T}^{2}=104,708 F(19,23)=3,0915, p<0.00557\right)$. In physically mature skulls all variables were dimorphic $\left(\mathrm{T}^{2}=621,236\right.$ $F(19,5)=7,1080, p<0,01951$ ) (Table 2). In physically immature skulls the Hotelling $\mathrm{T}^{2}$ test could not be computed. However, Student t-test showed than only one measurement (greatest width of internal nasal opening) was non-dimorphic $(p=0.057)$, while the other variables were dimorphic $(p<0.001)$ (Table 3$)$.

The discriminant analysis classified four variables (palate length-LP, rostral width-RW, palate width in molar 1-PM1W and greatest width of condylo-occipitalCOW) as dimorphic for male and female physically mature skulls (Wilks' Lambda $=0.10674 ; F(4,30)=62.763$; $p<0.00001)$. The discriminant function showed $100 \%$ of success in the correct classification of sex. The functions by sex for physically mature skulls were: a)

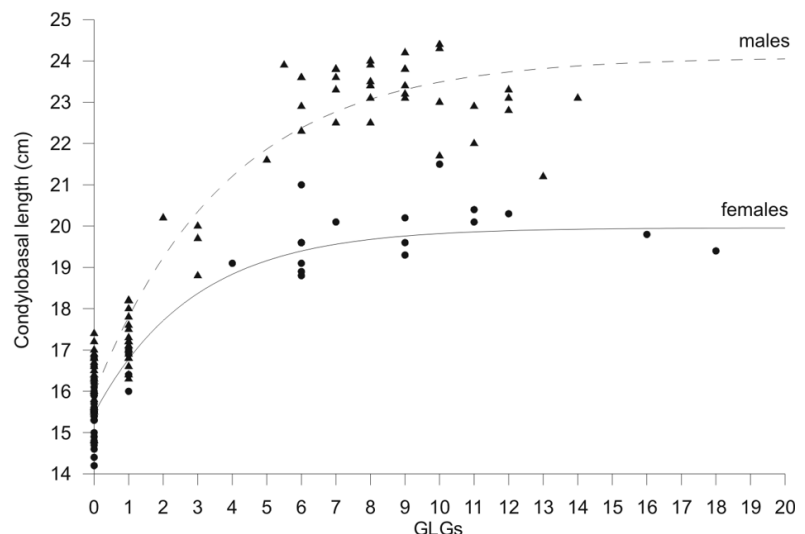

b)

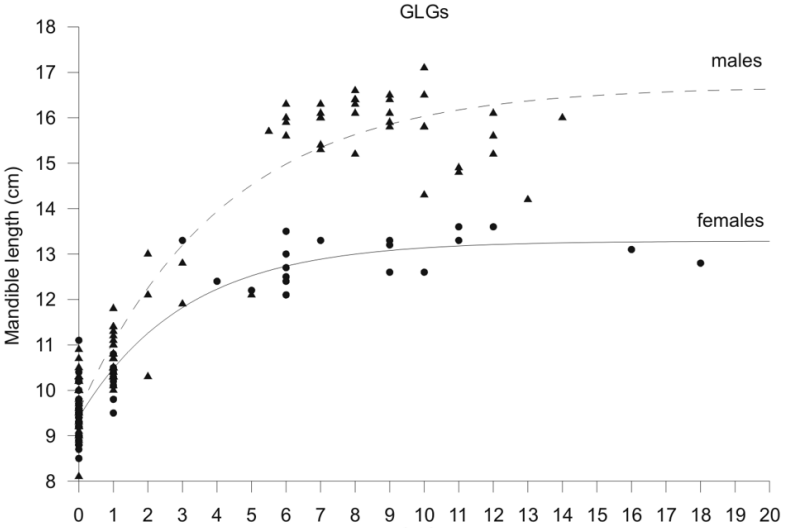

c)

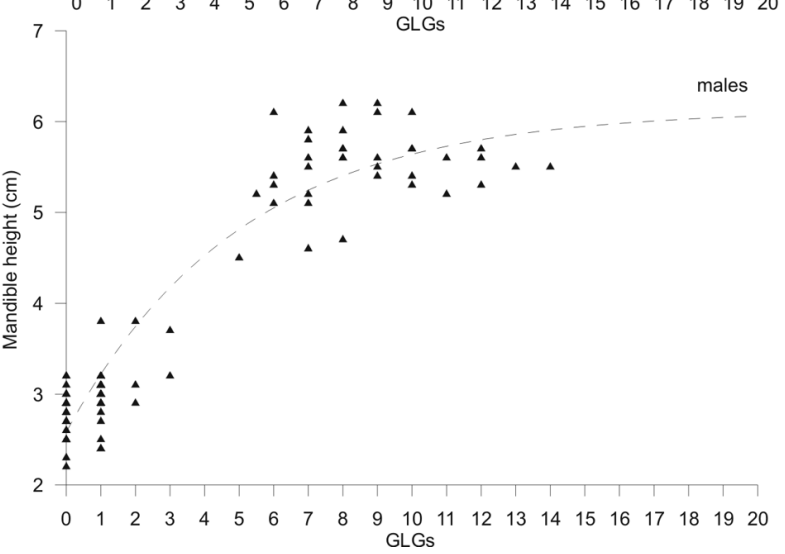

Figure 4. Von Bertalanffy growth curve for Arctocephalus australis. a) condylobasal length, b) mandible length and c) mandible height (growth curve only for males). ( $\Delta$ ) males, (•) females.

$\sigma=-545.35+84.06(\mathrm{LP})-11.19(\mathrm{RW})-43.18(\mathrm{PW} 1 \mathrm{~W})+$ $84.73(\mathrm{COW})$

ㅇ $=-397.37+72.23(\mathrm{LP})-18.71(\mathrm{RW})-34.69(\mathrm{PW} 1 \mathrm{~W})+$ $78.46(\mathrm{COW})$

\section{Analysis of non-metric characters}

The analysis of the degree of wear at the apex of the crown in the upper canine tooth of males started at 5 years old $(\mathrm{n}=48$ males $)$ and at six years $(\mathrm{n}=20)$ in females. The analysis of the degree of opening of the pulp cavity showed 
Table 2. Descriptive statistics of the metric characters $(\mathrm{cm})$ from physically immature skulls of males and females of Arctocephalus australis, from Rio Grande do Sul coast, Brazil.

\begin{tabular}{|c|c|c|c|c|c|c|c|c|c|c|c|}
\hline \multirow{2}{*}{ MEASUREMENTS } & \multicolumn{5}{|c|}{$\sigma^{\prime}$} & \multicolumn{6}{|c|}{ 우 } \\
\hline & $\mathrm{n}$ & MEAN & MIN. & MAX. & SD & $\mathrm{n}$ & MEAN & MIN. & MAX. & SD & $p$ \\
\hline 1. Condylobasal length & 61 & 18.38 & 14.80 & 23.90 & 2.77 & 33 & 15.76 & 14.80 & 23.90 & 0.93 & $* * *$ \\
\hline 2. Basilar length of Hensel & 61 & 16.47 & 13.00 & 21.60 & 2.50 & 33 & 14.05 & 13.00 & 21.60 & 0.87 & $* * *$ \\
\hline 3. Upper post canine length & 50 & 3.52 & 2.40 & 9.00 & 0.86 & 38 & 2.71 & 2.40 & 9.00 & 0.35 & $* * *$ \\
\hline 4. Zygomatic width & 69 & 4.51 & 3.40 & 9.80 & 0.65 & 46 & 4.07 & 3.40 & 9.80 & 0.25 & $* * *$ \\
\hline 5. Rostral width & 67 & 9.91 & 4.00 & 14.00 & 1.82 & 36 & 8.78 & 4.00 & 14.00 & 0.64 & $* * *$ \\
\hline 6. Mastoid width & 68 & 8.78 & 3.00 & 13.10 & 1.84 & 38 & 7.68 & 3.00 & 13.10 & 0.83 & $* * *$ \\
\hline 7. Skull height ${ }^{\text {a }}$ & 69 & 6.56 & 5.70 & 8.30 & 0.69 & 43 & 6.18 & 5.70 & 8.30 & 0.50 & $* * *$ \\
\hline 8. Palate length & 57 & 7.20 & 4.10 & 10.30 & 1.38 & 27 & 6.05 & 4.10 & 10.30 & 0.37 & $* * *$ \\
\hline 9. Palate width in molar 1 & 53 & 1.81 & 1.20 & 6.60 & 0.83 & 37 & 1.29 & 1.20 & 6.60 & 0.19 & $* * *$ \\
\hline 10. Palate width in molar 3 & 51 & 2.13 & 1.50 & 3.50 & 0.47 & 35 & 1.73 & 1.50 & 3.50 & 0.20 & $* * *$ \\
\hline 11. Palate width in molar 5 & 50 & 2.54 & 1.90 & 4.90 & 0.57 & 33 & 2.04 & 1.90 & 4.90 & 0.24 & $* * *$ \\
\hline 12. Greatest width of condylo-occipital & 70 & 4.46 & 2.60 & 5.60 & 0.47 & 44 & 4.18 & 2.60 & 5.60 & 0.28 & $* * *$ \\
\hline 13. Greatest length of nasal & 20 & 3.31 & 2.40 & 4.10 & 0.52 & 6 & 2.30 & 2.40 & 4.10 & 0.15 & $* * *$ \\
\hline 14. Constriction interorbital width & 70 & 2.35 & 1.60 & 4.10 & 0.51 & 44 & 1.91 & 1.60 & 4.10 & 0.21 & $* * *$ \\
\hline 15. Supraorbital process width & 69 & 3.80 & 2.10 & 5.80 & 0.69 & 44 & 3.32 & 2.10 & 5.80 & 0.33 & $* * *$ \\
\hline 16. Greatest width of internal nasal opening & 57 & 2.34 & 1.40 & 14.40 & 1.68 & 30 & 1.75 & 1.40 & 14.40 & 0.19 & 0.057 \\
\hline 17. Mandible length & 70 & 11.05 & 1.80 & 16.30 & 2.72 & 45 & 9.76 & 1.80 & 16.30 & 0.96 & $* * *$ \\
\hline 18. Mandible width & 70 & 1.75 & 1.10 & 10.20 & 1.16 & 46 & 1.24 & 1.10 & 10.20 & 0.22 & $* * *$ \\
\hline 19. Mandible height ${ }^{\mathrm{b}}$ & 70 & 3.29 & 1.00 & 6.10 & 1.07 & 45 & 2.74 & 1.00 & 6.10 & 0.37 & $* * *$ \\
\hline
\end{tabular}

(a) at insertion basisphenoidal-interparietal-occipital suture, $\left({ }^{b}\right)$ at coronoid process, $\left({ }^{* * *}\right) p<0.001$

that the upper canine tooth with opening of the pulp cavity smaller or equal to $2 \mathrm{~mm}$ started at six years of age in males $(n=18)$ and females $(n=3)$. The pulp cavity was closed at 10 years of age in males $(n=4)$ and six in females $(n=9)$.

The cranial sutures presented variations related to age. The occipito-parietal suture started to be closed-invisible at three years of age in males $(n=41)$ and at four years in females $(n=18)$. In males, the interparietal suture started to be close-invisible at five years of age $(n=34)$ and at four years of age in females $(n=16)$. The premaxillary-maxillary suture was also closed-visible in males at 14 years of age $(n=85)$ and eight years in females $(n=55)$. However, only one male presented the suture premaxillary-maxillary closed at eight years of age. The interfrontal suture also was closed-visible in males at 14 years of age $(n=85)$ and at 18 years in females $(n=55)$. In three males this suture started to be invisible at six to eight years of age.

The analysis of six non-metric characters using Kolmogorov-Smirnov test (K-S) showed differences between physically immature $(\mathrm{n}=116)$ and mature skulls $(n=40)$ in all characters analyzed $(p<0.001)$ (Tables 2 and $3)$. Only the greatest width of internal nasal opening in physically immature skulls was not dimorphic $(p=0.057)$ (Table 2).

No sexual dimorphism was observed when the developmental classes (physically immature and physically mature) were analyzed separately.

\section{Individual variation}

In males $(n=23)$, the palate width in molar 3 presented the highest coefficient of variation $(\mathrm{CV}=11.63 \%)$, while condylobasal length and basilar length of Hensel presented the smallest values ( $\mathrm{CV}=3.5 \%)$ (Table 3). In females ( $\mathrm{n}=17)$, the greatest length of nasal presented the highest coefficient of variation $(\mathrm{CV}=11.83 \%)$, while the skull height presented the smallest $(\mathrm{CV}=4.36 \%)$ (Table 3$)$.

All characters (Table 3 ) were included in the principal component analysis (PCA). The component I explained $80.2 \%$ of the total variation, with all negative coefficients and eigenvalue of correlation matrix of 15.24. The component II explained $4.6 \%$ of the observed variability and eigenvalue of correlation matrix of 0.87 (Figure 5). In the component I (x), all the characters presented factor loadings more than 0.700 , but on the component II (y) the 
higher factor loadings were palate width in molar 3 (0.4976) and palate width in molar 5 (0.4765).

\section{Dental formula}

The number of incisive (i) and canine (c) teeth in each maxillary and mandibular branch were the same in 157 skulls $(i=3 / 2 ; c=1 / 1)$. The number of upper post canine teeth in the right (pcr) and left (pcl) mandibular branch were also the same ( $\mathrm{pcr}=6 ; \mathrm{pcl}=5)$. The number of inferior post canine teeth was also always the same $(p c=5)$.

However, variations occurred $(n=21)$ in the number of upper post canine teeth right and left, respectively: 7 - 6 $(\mathrm{n}=1) ; 7-5(\mathrm{n}=1) ; 6-6(\mathrm{n}=1) ; 4-3(\mathrm{n}=1) ; 5-5(\mathrm{n}=11)$ and 5 - $6(n=6)$. These variations were independent of sex. Therefore the dental formula (DF) was:

$$
\mathrm{DF}=(\mathrm{i} 3 / 2+\mathrm{c} 1 / 1+\operatorname{pcr} 4-7 / 5+\operatorname{pcl} 3-6 / 5)=(31-37)
$$

\section{Discussion}

Growth parameter values obtained by von Bertalanffy model fitted to metric variables-at-age of male and female $A$. australis showed a differentiated development between sexes. The

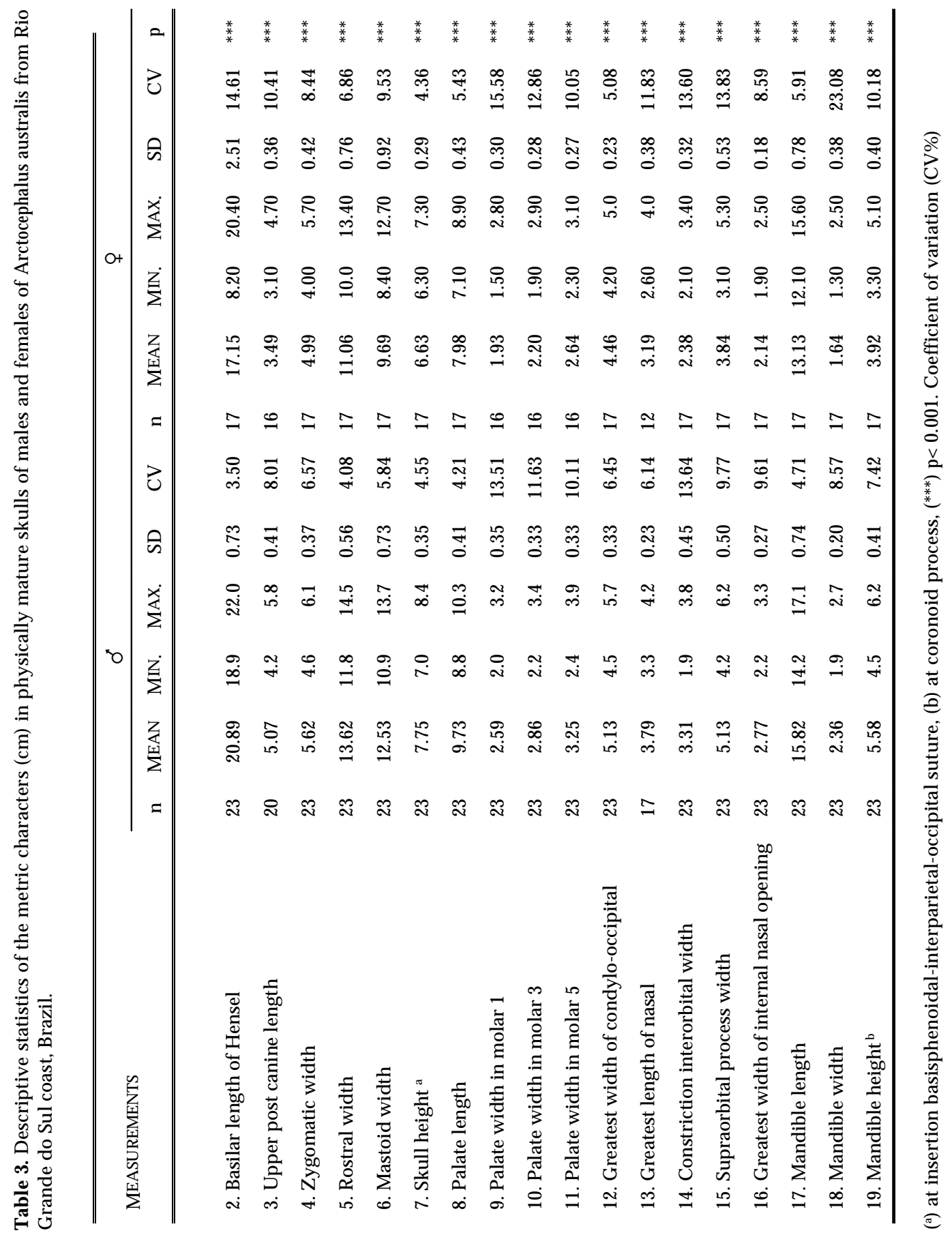




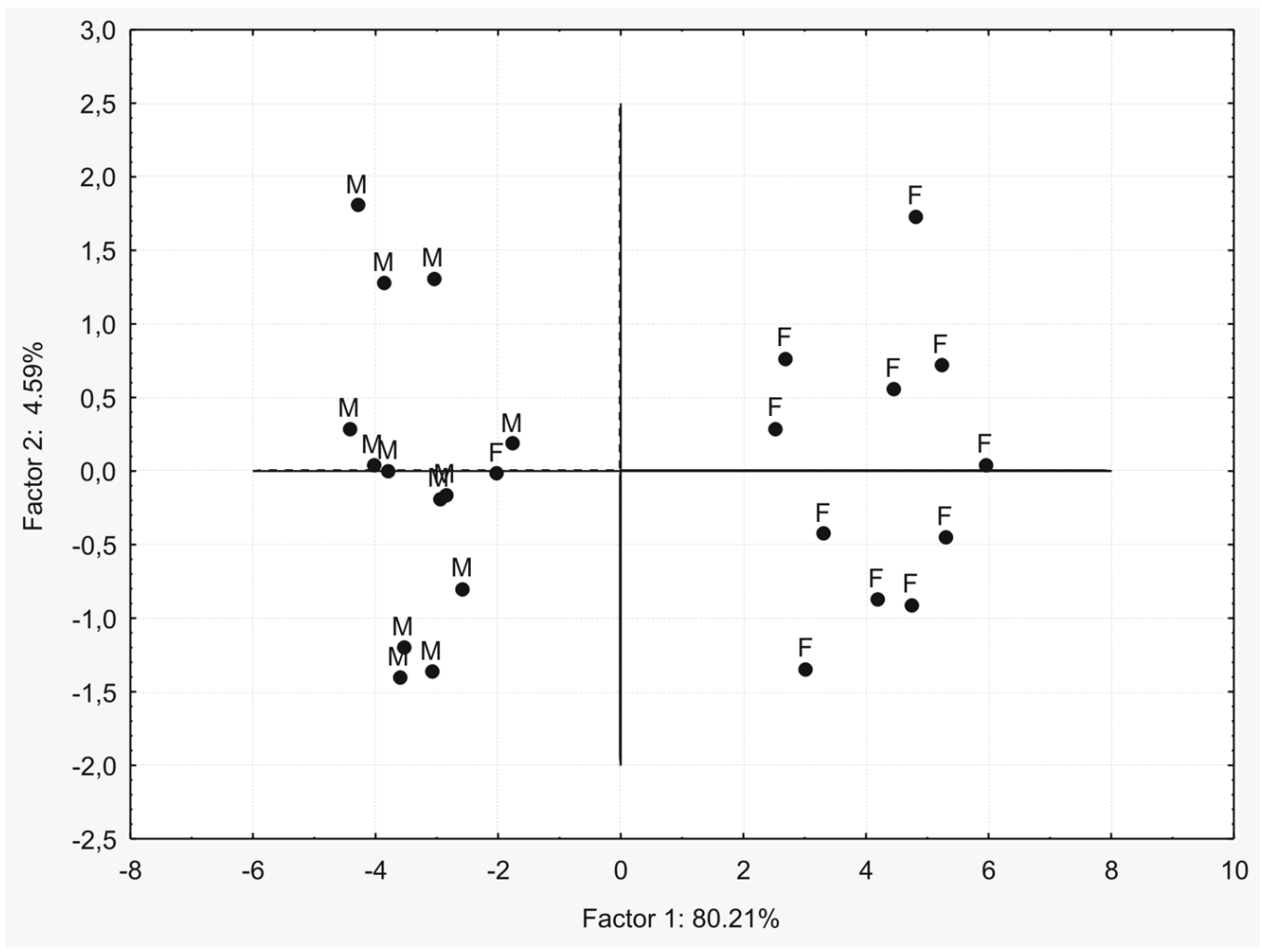

Figure 5. Results of principal component analysis (PCA) based on metric characters of physically mature skulls of Arctocephalus australis. (M) male, (F) female.

female skull presented an early maturation in relation to the male skull. These characters for males and females are related to the neural development (e.g., braincase, visual and hearing apparatus) and somatic development (e.g., feeding, breathing and vocalizing apparatus). In males, the upper post canine length, greatest width of internal nasal opening, greatest length of nasal and mastoid width showed a faster growth than females. These characters are related to somatic and neural development (hearing). The supraorbital process width, related to nervous system (visual apparatus), had a slower growth in both sexes.

The sexual dimorphism observed in skull of $A$. australis corroborates the differences observed in other studies (VazFerreira, 1982; Ximénez et al., 1984; Páez, 1989; Dremer and Ferigolo, 1996; Sanfelice, 2004). Similar patterns of sexual dimorphism occur in many other polygynous species such as Otaria flavescens (Rosas et al., 1993; Sanfelice, 2004), Arctocephalus forsteri and Arctocephalus pusillus doriferus (Brunner, 1998; 2000).

All the characters used in male and female skulls in this study were dimorphic, but in physically immature skulls greatest width of internal nasal opening was nondimorphic. The lack of dimorphism in this character implies similar functions for males and females when they are physically immature.

Sexual growth differences should be greatest in highly polygynous species (Clutton-Brock et al., 1982). Often times ontogenetic scaling is presented in the literature to explain sexual dimorphism (Leutenegger and Larson, 1985). The Pinnipedia contain some of the most spectacular examples of sexual size dimorphism, which are frequently used to illustrate the theory of sexual selection (Lindernfors et al., 2002). Shape differences between adult males and females result from the extension of relative growth (shape change) in the smaller females to larger overall size in males (Shea, 1986). In most pinnipeds, females reach the reproductive age much earlier than males, devoting a lot of energy to their offspring. Thus, ability for further somatic growth is limited. In contrast, males do not provide parental care and in most cases reach maturity later in life (Boness, 1991). Lindernfors et al. (2002) did not find a significant relationship between body size and sexual size dimorphism in pinnipeds, and postulated that sexual size dimorphism in pinnipeds was a result of selection working on males alone.

When comparing skull measurements from this study to those obtained for the same species in other localities, similarities and differences are observed. The maximum condylobasal length of physically mature males and females collected in the coast of Rio Grande do Sul was similar to the maximum reported for individuals from Uruguay (Vaz-Ferreira, 1982; Ximénez et al., 1984) and the Falkland Islands (Sivertsen, 1954). Similar measurements for some skull characters and the same age classes observed for both sexes were also obtained by Páez (1989) in individuals from Uruguayan islands. Differences were 
observed in the asymptotic length and age of physical maturity of the skull in the above studies. However, these differences could be related to different methodologies used for estimating age and accuracy for detecting GLGs. Batallés et al. (1990) determined the growth of body length using the von Bertalanffy model fitted for A. australis (500 males and 500 females) from Isla de Lobos taken from 1984 to 1987 , with males being $22 \%$ larger than females. The $90 \%$ of asymptotic size was reached at 10.5-11.5 years of age in males and 7.5 years in females. These ages are close to the physical maturity of skull obtained in this study.

All analyzed non-metric characters showed differences between physically immature and physically mature skulls, but these characters were not useful to determine the sex in skull of $A$. australis. The cranial sutures showed variations related to age for males and females. The premaxillary-maxillary and interfrontal sutures showed a greater variation in relation to age when the condition closed-visible was analyzed. The occipito-parietal and the interparietal sutures started to be closed-invisible at earlier ages in males and females. The degree of wear at the apex of the crown in the upper canine tooth started at similar age for males and females. The pulp cavity closure was observed earlier in females than males, which is probably related to the smaller size of the canine tooth in females.

Differences were observed in the number of post canine teeth in this study and those cited for the species in Uruguay (VazFerreira, 1982) as well as for other species of Arctocephalus: A. gazella, A. forsteri and A. galapagoensis (King, 1983; Jefferson et al., 1993); A. towsendii, A. philippi, A. tropicalis and A. pusillus (Jefferson et al., 1993). This could be explained by differential counting method applied by these authors, i.e., recording the minimum and maximum number of alveoli in both mandibular branches, indistinctly if at right or left position. Differences between physically immature and mature skulls of $A$. australis observed in this study were also observed by Sanfelice (2004), using traditional and geometric morphometrics techniques. Sexual dimorphism in canine teeth of A. australis was present in physically immature and mature individuals (Molina-Schiller and Pinedo, 2004).

The principal component analysis (PCA) of physically mature skulls showed a clear separation between males $(n=23)$ and females $(n=17)$. Despite the prolonged collection period (20 years), sample sizes of physically mature skulls of $A$. australis were relatively small in the present study, which reflects the lower occurrence of this age class in strandings along the coast of Rio Grande do Sul. The variation detected in the skulls characters of males and females showed that most of the variance between the sexes is expressed in the overall size of cranial characteristic, with shape expressing much less variation. They were considered to represent the individual variation of animals occurring along the coast of Rio Grande do Sul. Results of the present study will be potentially useful in future morphometrics studies for the species, including analyses of geographical variation among populations of Uruguay, Argentina, Falkland Islands, Chile and Peru.

Future genetic and morphometric studies (traditional and geometric morphometrics techniques) along the entire distribution of the species will provide insights into stock management and conservation.

\section{Acknowledgments}

Thanks to all those involved in fieldwork in Rio Grande. This study was part of a Master Thesis of D. MolinaSchiller, which was supported by grants from CNPq (136348/96-3) and FAPERGS (96/60143.7). We thank Dr. Larissa de Oliveira-GEMARS, Dr. Susana PedrazaCENPAT and Dr. Nélio Barros for reviewing the English and for their helpful comments on the manuscript.

\section{References}

Batallés, L.M., Pin, O. and Lima, M. (1990) Estudio del crecimiento del lobo fino sudamericano (Arctocephalus australis) en Isla de Lobos, Uruguay. Frente Marítimo 7(A): 69-73.

Bertalanffy, L. (1957) Quantitative laws in metabolism and growth. Quarterly Review of Biology 32: 217-231.

Bonner, W.N. (1981) Southern fur seals, Arctocephalus (Geoffroy Saint-Hilaire and Cuvier, 1826). Pages 161-208 in Ridgway, S.H. and Harrison, R.J. (Eds) Handbook of Marine Mammals, Vol.1: The Walrus, Sea Lions, Fur Seals and Sea Otter. Academic Press, London.

Boness, D.J. (1991) Determinants of mating systems in the Otariidae (Pinnipedia). Pages 1-44 in Renouf, D. (Ed.) The Behaviour of Pinniped. Chapman and Hall Ltd.

Brunner, S. (1998) Cranial morphometrics of the southern fur seals Arctocephalus forsteri and A. pusillus (Carnivora: Otaridae). Australian Journal of Zoology 46: 67-108.

Brunner, S. (2000) Cranial morphometrics of fur seals and sea lions (Family: Otariidae)- systematics, geographic variation and growth. Ph.D. Thesis. University of Sydney, Sydney-Australia. 254pp.

Calzada, N., Aguilar, A., Lockyer, C. and Grau, E. (1997) Patterns of growth and physical maturity in the western Mediterranean striped dolphin, Stenella coeruleoalba (Cetacea: Odontoceti). Canadian Journal of Zoology 75: 632-637.

Clutton-Brock, T.H., Guinness, F.E. and Albon, S.D. (1982) Red Deer. Behavior and Ecology of Two Sexes. University of Chicago Press, Chicago.

Crespo, E.A., Schiavini, A.C.M.G., Perez Macri, Reyes, L. and Dans. S. (1994) Estudios sobre determinación de edad en mamíferos marinos del Atlântico Sudoccidental. Pages 31-55 in Anales IV Reunión de Trabajo de Especialistas en Mamíferos Acuáticos de América del Sur, 12-15 November 1990, Valdivia, Chile.

Drehmer, C.J. and Ferigolo, J. (1996) Descrição do sincrânio de Arctocephalus australis (Pinnipedia, Otariidae). Iheringia, Série Zoológica, Porto Alegre 81: 63-74.

Jefferson, T.A., Leatherwood, S. and Webber, M.A. (1993) FAO species identification guide. Marine Mammals of the World. Roma, FAO.

King, J.E. (1983) Seals of the world. British Museum (Natural History) and Cornell University Press, Cambridge.

Leutenegger, W. and Larson, S. (1985) Sexual dimorphism in the postcranial skeleton of New World primates. Folia Primatologica 44: 82-95.

Lindernfors, P., Tulberg, B.S. and Biuw, M. (2002) Phylogenetic analyses of sexual selection and sexual size 
dimorphism in pinnipeds. Behavioral Ecology and Sociobiology 52: 188-193.

Majluf, P. and Trillmich, F. (1981) Distribution and abundance of sea lions (Otaria byronia) and fur seals (Arctocephalus australis) in Peru. Zeitschrift für Saügetierkunde 46: 384-393.

Molina-Schiller, D.M. (2000) Age and cranial development of the South American fur seal, Arctocephalus australis (Zimmermann, 1783) (Carnivora: Otariidae) in the coast of Rio Grande do Sul, Brazil. Master Thesis. Fundação Universidade Federal do Rio Grande (FURG). Rio Grande, RS, Brazil. 117pp.

Molina, D.M. and Oporto, J.A. (1993) Comparative study of dentine staining techniques to estimate age in the Chilean dolphin, Cephalorhynchus eutropia (Gray, 1846). Aquatic Mammals 19(1): 45-48.

Molina-Schiller, D. and Pinedo, M.C. (2004) Using canine teeth for sex determination of the South American fur seal, Arctocephalus australis. The Latin American Journal of Aquatic Mammals 3(1): 19-24.

Molina-Schiller, D. and Pinedo, M.C. (2004) Growth layer pattern in Arctocephalus australis canine teeth: evaluation of techniques for age determination. The Latin American Journal of Aquatic Mammals 3(2) : 107-118.

Oliveira, L.R. (1999) Caracterização dos padrões de ocorrência dos pinípedes (Carnívora:Pinipedia) ocorrentes no Litoral do Rio Grande do Sul, Brasil entre 19933 1999. Thesis. Pontifícia Universidade Católica do Rio Grande do Sul (PUCRS). Porto Alegre, RS, Brazil. 154pp.

Oliveira, L.R. and Danilewicz, D. (2000) Crescimento dos machos e dimorfismo sexual no lobo-marinho sul-americano, Arctocephalus australis, no Rio Grande do Sul, sul do Brasil. Page 97 in Abstracts, IX Reunión de Trabajo de Especialistas en Mamíferos Acuáticos de América del Sur and III Congreso de la Sociedad Latinoamericana de Especialistas en Mamíferos Acuáticos de América del Sur, 29 October - 3 November, Buenos Aires, Argentina.

Oliveira, L.R., Malabarba, L.R. and Majluf, P. (1999) Variação geográfica em crânios do lobo-marinho sul-americano Arctocephalus australis (Zimmermann, 1783) das populações do Brasil e Peru. Comunicações do Museu de Ciências e Tecnologia da Pontifícia Universidade Católica do Rio Grande do Sul 12: 179-192.

Oliveira, L.R., Hingst-Zaher, E. and Morgante, J.S. (2001) Análise do dimorfismo sexual craniano do lobo-marinho sulamericano Arctocephalus australis (Carnivora: Otariidae) através de técnicas de morfometria tradicional e geométrica. Pages 113-114 in Abstracts, I Congresso Brasileiro de Mastozoologia, 6-9 September 2001, Porto Alegre, Brazil.

Páez, E.A. (1989) Estudio del crecimiento en medidas craneales del lobo fino sudamericano, Arctocephalus australis (Zimmermann, 1783). Lic. Thesis, Universidad de la República, Uruguay. 93pp.

Páez, E. (1999) Bootstrap and power analysis utilization in abundance estimations of Arctocephalus australis pups. Pages 55-74 in Rey, M., Amestoy, F. and Arena, G. (Eds) Synopsis on the biology and ecology of South American fur seals and southern sea lions of Uruguay. Guidelines to their management and administration. (Instituto Nacional de Pesca (INAPE) Ministerio de Ganadería, Agricultura y Pesca (MGAP) Programa de las Naciones Unidas para el Desarrollo (PNUD) Technical Report INAPE-PNUD URU/92/003 Montevideo.

Perrin, W.F. (1984) Patterns of geographical variation in small cetaceans. Acta Zoologica Fennica 172: 137-140.

Perrin, W.F. and Myrick, A.C. Jr. (Eds) (1980) Age Determination of Toothed Whales and Sirenians. Reports of the International Whaling Commission (special issue 3). Cambridge, UK.

Pinedo, M.C. (1990) Ocorrência de pinípedes na costa brasileira. Garcia de Orta. Série Zoologia Lisboa 15(2): 37-48.

Pinedo, M.C. (1991) Development and variation of the franciscana, Pontoporia blainvillei. Ph.D. Thesis. University of California, Santa Cruz, USA.. 406pp.

Pinedo, M.C., Rosas, F.C.W. and Marmontel, M. (1992) Cetáceos e pinípedes do Brasil: Uma revisão dos registros e guia para identificação das espécies. United Nations Environmental Programme (UNEP)/FUA, Manaus.

Repenning, C.A., Peterson, R.S and Hubbs, C.L. (1971) Contribution to the systematics of the southern fur seals, with particular reference to the Juan Fernandez and Guadalupe Species. Antarctic Research Series 18: 1-34.

Rosas, F.C.W., Haimovici, M. and Pinedo, M.C. (1993) Age and growth of the South American sea lion, Otaria flavescens (Shaw, 1800), in southern Brazil. Journal of Mammalogy 74(1): 141-147.

Sanfelice, D. (2004) Ontogenia craniana comparada de Arctocephalus australis, Callorhinus ursinus e Otaria byronia (Otariidae: Pinnipedia). Ph.D. Thesis. Univeridade Federal do Rio Grande do Sul (UFRGS). Porto Alegre, RS, Brazil. 153pp.

Schiavini, A.C.M., Lima, M. and Batallés, L.M. (1992) Growth structures of maxillary canines of the southern fur seal (Arctocephalus australis). Marine Mammals Science 8(1): 89-93.

Schnell, G.D., Douglas, M.E. and Hough, D.J. (1985) Sexual dimorphism in spotted dolphins (Stenella attenuata) in the eastern tropical Pacific Ocean. Marine Mammal Science 1(1): 1-14.

Shea, B.T. (1986) Ontogenetic approaches to sexual dimorphism in anthropoids. Human Evolution 1: 97-110.

Sivertsen, E. (1954) A survey of the eared seals (family Otariidae) with remarks on the antarctic seals collected by $M / K$ "Norvegia" in 1928-1929. Scientific Result of the Norwegian Antartic Expeditions 36. Det Norske Videnskaps-Akademi I Oslo.

Vaz-Ferreira, R. (1982) Arctocephalus australis Zimmermman. South American fur seal. Pages 497-508 in Mammals in the Seas. FAO Fisheries Series 5(4), Rome, Italy.

Ximénez, I., Lima, M., Ponce de León, A., Batallés, L.M. and Malek, A. (1984) Estudio estadístico de relaciones craneales en el "Lobo fino" Sudamericano, Arctocephalus australis (Zimmermmann, 1783). Pages 3-33 in Anales de Industria Lobera y Pesquera del Estado (I.L.P.E), Montevideo, Uruguay. 